\title{
SPATIAL SUSCEPTIBILITY OF ARCHAEOLOGICAL SITES TO EARTHQUAKE ENVIRONMENTAL EFFECTS (EEES)
}

\author{
Minos-Minopoulos D. ${ }^{1,2}$, Dominey-Howes D. ${ }^{3}$ and Pavlopoulos K. ${ }^{4,1}$ \\ ${ }^{1}$ Harokopio University, Department of Geography, 70 El. Venizelou Str., Kallithea, 17671 , \\ Athens, Greece,dminou@hua.gr, kpavlop@hua.gr \\ ${ }^{2}$ Ephorate of Paleoanthropology - Speleology, Ministry of Culture and Sports, Ardittou 34B, 116 \\ 34, Athens Greece \\ ${ }^{3}$ The University of Sydney, School of Geosciences, Sydney NSW 2050, Australia, dale.dominey- \\ howes@sydney.edu.au \\ ${ }^{4}$ Paris Sorbonne University Abu Dhabi, P.O. 38044 Abu Dhabi, UAE, \\ Kosmas.Pavlopoulos@psuad.ac.ae
}

\begin{abstract}
The study examines a semi-quantitative indicator based method to assess the spatial susceptibility of archaeological sites to the secondary Earthquake Environmental Effects (EEEs) of ground liquefaction, landslides and tsunami. The method was applied at 16 archaeological sites allowing the identification of the EEEs each site is susceptible to and their prioritization at a national and regional level through the Spatial Susceptibility index (SSi). Results indicate that the majority of the sites are susceptible to at least one Earthquake Environmental Effect. This highlights their contribution to the vulnerability of archaeological sites to earthquake hazard and the necessity for the integration of spatial susceptibility parameters in vulnerability assessment studies for cultural heritage protection.
\end{abstract}

Keywords: spatial susceptibility index, ground liquefaction, landslides, tsunami, cultural heritage.

\section{Пєрí $\eta \psi \eta$}

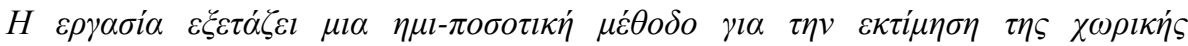

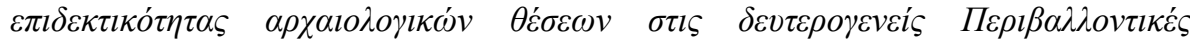

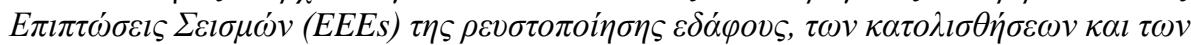

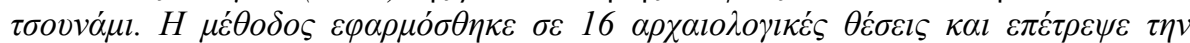

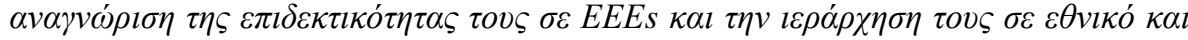

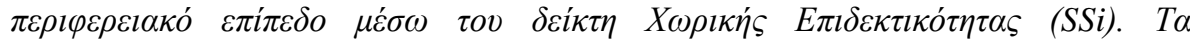

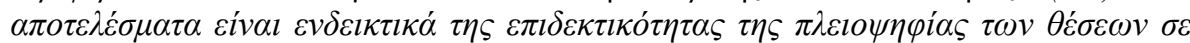

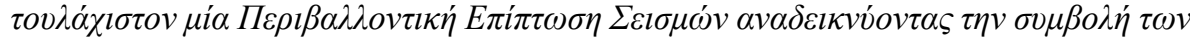

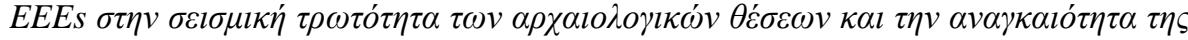

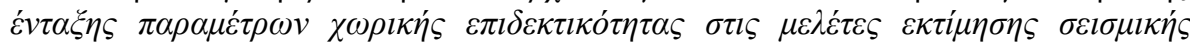

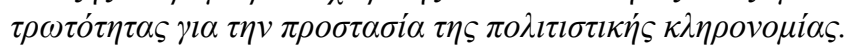

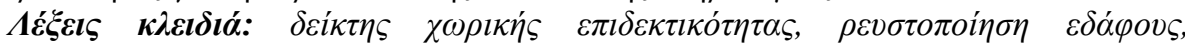

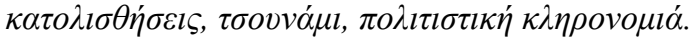




\section{Introduction}

Cultural heritage due to its intrinsic properties, its physical, social, economic and institutional characteristics is considered as highly vulnerable to natural hazards. The vulnerability of cultural heritage is regarded as the susceptibility or exposure of heritage property to hazards (UNESCO 2010). It expresses the inherent weakness of the heritage property due to its location and consequently its exposure to primary or secondary hazards (Jigyasu, 2005).

Earthquake Environmental Effects (EEEs) are co-seismic geological phenomena that either relate directly to the surface expression of the seismogenic source (known as primary effects) or they are induced by ground shaking (and are known as secondary effects) (Michetti et al., 2007, 2015). The susceptibility of an archaeological site to these effects represents a crucial vulnerability parameter to earthquake hazard since the sensitivity of a site to the occurrence of EEEs during a seismic event, relates directly to landscape evolution and potential damage effects on the monuments of the site.

This study aims to develop a low cost semi-quantitative method to screen and assess the spatial susceptibility of archaeological sites to the secondary EEEs of ground liquefaction, landslides and tsunamis induced by ground shaking and controlled by the local geological - geomorphological setting (Serva et al., 2015; Minos-Minopoulos, 2015). The method will allow the identification of susceptible sites to secondary EEEs and their prioritization at a regional and national level through a Spatial Susceptibility index for further studies and appropriate vulnerability reduction measures.

\section{Methods}

The archaeological sites selected for this study are located in the regions of Corinth, Samos, Kos and Santorini islands (Tab. 1). The selection of these regions and sites aimed to capture a variety of geotectonic regimes, geomorphological settings, land use, archaeological periods and typologies.

Table 1 - The archaeological sites under study.

\begin{tabular}{cccc}
\hline Corinth & Samos & Kos & Santorini \\
\hline Ancient Agora & Roman Baths & Neratzia Fortress & \\
Theatre & Eupalinos Tunnel & Ancient Agora & Ancient Thera \\
Odeion & Logothetis Castle & Altar of Dionysus & Akrotiri \\
Kenchreai Harbour & Heraion & Archaeological Site & \\
Lechaion Harbour & & Asklepieion & \\
\hline
\end{tabular}

The archaeological sites were examined in terms of their geological and geomorphological properties through spatial susceptibility indicators for the secondary EEEs of ground liquefaction, landslides and tsunami. Each EEE indicator is composed of a selection of geological and geomorphological factors based on previous studies. A number of parameters such as i) historical records and previous studies in the field of each environmental effect, ii) Earthquake Archaeological Effects (EAEs) related to ground deformation (Rodríguez-Pascua et al., 2011) and iii) interventions performed either during antiquity or during modern times indicative of active geological and geomorphological processes, were also included in the assessment of each EEE indicator through the Archaeological Site Factor.

The factors were assigned with weights according to their relative importance for the aims of this study. Their relative importance is based, where available, on expert qualitative judgments of previous studies. Each factor's classes were standardized with linear scaled values from 0 to 1 following the Analytic Hierarchy Process (Saaty, 1987) with the assistance of the M-MACBETH software (Bana e Costa et al., 2005) in order to address concerns on subjective transformation of qualitative judgments to numerical scores. The sum of the selected factors through the weighted linear combination method composes the susceptibility indicator for each effect. The susceptibility indicators are rated on a scale from 0 (not susceptible) to 1 (very high susceptibility). 
Data collection from each archaeological site was based primarily on field survey forms. Additional data were obtained from 1:5000 scale base maps, 1:50000 scale geological maps, historical records and available geological and geotechnical studies carried out in the immediate surroundings of each archaeological site.

\subsection{Liquefaction Susceptibility indicator $(\mathrm{LqSi})$}

The susceptibility of archaeological sites to the EEE of ground liquefaction is assessed through the factors of i) depositional environment (D.E.), ii) water table depth (W.T), iii) geological age of the deposits (A) and iv) archaeological site indications (S.F.) (Tab. 2). The factors were assigned with weights $(w)$ according to their relative importance for the aims of this study and their linear weighted sum through Equation 1 represents the Liquefaction Susceptibility indicator ( $L q S i)$.

Equation 1 - Liquefaction Susceptibility indicator formula

$$
L q S i=w 1 D . E .+w 2 W . T .+w 3 A .+w 4 S . F .
$$

Table 2 - The spatial susceptibility factors for the Liquefaction Susceptibility indicator (LqSi) with weights, classes and scores.

\begin{tabular}{|c|c|c|c|c|}
\hline LqSi & Factor & Weight & Classes & Score \\
\hline \multirow{15}{*}{ 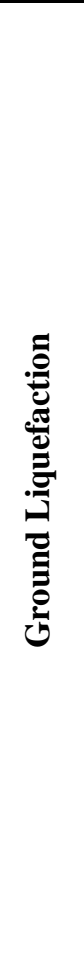 } & \multirow{3}{*}{$\begin{array}{l}\text { Depositional } \\
\text { Environment } \\
\quad \text { (D.E.) }\end{array}$} & \multirow[t]{3}{*}{0.4} & $\begin{array}{c}\text { Continental: river channel, flood plain delta } \\
\text { and fan-delta, lacustrine and playa,colluvium, } \\
\text { dunes, loess, tephra, sebka } \\
\text { Coastal zone: delta, estuarine, lagoonal, low } \\
\text { wave energy beach deposits, fore shore } \\
\text { deposits poorly compacted artificial sand fills }\end{array}$ & 1 \\
\hline & & & $\begin{array}{l}\text { Continental: alluvial-fan and plain deposits } \\
\text { Coastal: high wave energy deposits }\end{array}$ & 0.6 \\
\hline & & & $\begin{array}{l}\text { Continental: talus, glacial till, tuff, residual } \\
\text { soils, marine terraces and plains, clay-rich } \\
\text { sediments, compacted artificial fill, bedrock }\end{array}$ & 0 \\
\hline & \multirow{5}{*}{$\begin{array}{l}\text { Ground water } \\
\text { table depth (m) } \\
\text { (W.T.) }\end{array}$} & \multirow{5}{*}{0.3} & $<3$ & 1 \\
\hline & & & $3-6$ & 0.85 \\
\hline & & & $6-10$ & 0.6 \\
\hline & & & $10-15$ & 0.3 \\
\hline & & & $>15$ & 0 \\
\hline & \multirow{3}{*}{$\begin{array}{l}\text { Age } \\
(\mathrm{A})\end{array}$} & \multirow{3}{*}{0.2} & Holocene & 1 \\
\hline & & & Pleistocene & 0.4 \\
\hline & & & Pre-Pleistocene & 0 \\
\hline & \multirow{4}{*}{$\begin{array}{l}\text { Archaeological } \\
\text { Site Factor } \\
\text { (S.F.) }\end{array}$} & \multirow{4}{*}{0.1} & Relevant studies & 1 \\
\hline & & & Past ground deformation indications & 0.6 \\
\hline & & & Slope stabilization works & 0.3 \\
\hline & & & None & 0 \\
\hline
\end{tabular}

The depositional environment factor (D.E.) determines the composition, sorting and degree of compaction of the deposits. Deposits with greater sorting and looser compaction are considered as highly susceptible in contrast to clay-rich deposits with a fine content of $>15 \%$ that are generally considered to have low susceptibility (Youd and Hoose, 1977; Obermeier, 2009). The detailed susceptibility classification of depositional environments (Youd and Hoose, 1977; Youd and Perkins, 1978; Youd, 1998) with the necessary adjustments have been grouped into three classes as presented in Table 2 and the classes were ranked with the assistance of the M-MACBETH software. 
The water table depth factor (W.T.) is considered as an important parameter for liquefaction susceptibility since liquefaction-susceptible soils must be saturated (Youd, 1998). The susceptibility decreases with increasing water table depth (Obermeier et al., 1990; Youd and Hoose, 1977; Youd, 1998) since liquefaction resistance increases with overburden pressure and age of sediment, both of which generally increase with depth. The classes and qualitative judgments by Youd (1998) are used in this study ranked with the assistance of the M-MACBETH software.

The geological age (A) of the deposits is another factor considered in the assessment of site susceptibility to ground liquefaction. According to Youd and Hoose (1977), the susceptibility of deposits decreases with age since they become more consolidated and therefore less prone to the manifestation of liquefaction. In this study, the susceptibility of sedimentary deposits in relation to their geological age is examined according to the qualitative classification made by Youd and Perkins (1978) ranked with the assistance of the M-MACBETH software.

Direct and/or indirect effects preserved in archaeological sites that could potentially relate to past ground liquefaction events provide useful information for their susceptibility assessment although further field investigations are considered necessary. These parameters are summarised as i) previous studies and records for archaeological sites on past earthquake induced liquefaction events and deformation, ii) indirect structural indications from potential Earthquake Archaeological Effects (EAEs) attributed to ground deformation (Rodríguez-Pascua et al., 2011) that could relate to the surface expression of ground liquefaction and iii) presence of slope stabilization works such as retaining or buttress walls that can also be considered as indirect indications of mitigation works against ground instabilities related to ground liquefaction. The classes are scored according to their degree of relevance to the effect of liquefaction.

\subsection{Landslide Susceptibility indicator $(\mathrm{LsSi})$}

The study focuses on identifying locations within the archaeological sites that are more prone to slope instabilities through selected factors summarised as i) slope angle (S.A.), ii) archaeological site indications (S.F.), iii) erosion (E), iv) lithology (L) and v) distance from tectonic lineaments (D.T.L.) (Tab. 3). The linear weighted sum of the factors through Equation 2 represents the Landslide Susceptibility indicator (LsSi).

\section{Equation 2 - Landslide Susceptibility indicator formula}

$$
L s S i=w 1 S . A .+w 2 S . F .+w 3 E+w 4 L+w 5 T . L . P .
$$

Taking into consideration the landslide susceptibility studies in Greece, their scale (1:50.000 and national scale), landslide types under study, limitations and the international literature on earthquake induced landslides, the slope angle factor (S.A.) was classified into four classes with the highest class being of $>30^{\circ}$ (Tab. 3). For the aims of this study the highest class includes slopes and escarpments susceptible to both landslides and rock falls. Class scores are based on the standardization of the Landslide Relative Frequency proposed by Sabatakakis et al. (2013).

The archaeological Site Factor (S.F.) represents an inventory of the site through direct and indirect parameters relating to slope instability. The factor is expressed through i) direct indications of slope instability through observations, records and previous studies, ii) indirect indications of slope instability expressed through Earthquake Archaeological Effects (EAEs) indicative of permanent ground deformation (Rodríguez-Pascua et al., 2011), iii) slope stabilization works through retaining and buttress walls indicative of landscape modification, levelling of slopes and works that aim to the stabilization of unstable slopes. The classes are scored according to their degree of relevance to the effect of landslides.

The erosion factor $(E)$ in this study represents an indirect indication of slope instability that relates to erosion processes and act as triggering parameters for instabilities in coastal slopes and continental slopes near streams. In this study, a combination of the Distance to Coast Factor by Alves et al. (2011) 
for a 1:10.000 scale and the distance from streams factor by Kouli et al. (2014) is applied at each site, with quantitative ranking and standardization with the assistance of the M-MACBETH software.

Table 3 - The spatial susceptibility factors for the Landslide Susceptibility indicator (LsSi) with weights, classes and scores.

\begin{tabular}{|c|c|c|c|c|}
\hline$\overline{\mathbf{L S S i}}$ & Factor & Weight & Classes & Score \\
\hline \multirow{22}{*}{ 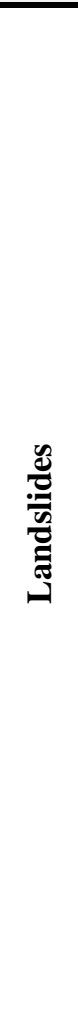 } & \multirow{4}{*}{$\begin{array}{l}\text { Slope Angle } \\
\text { (S.A.) }\end{array}$} & \multirow{4}{*}{0.3} & $>30^{\circ}$ & 1 \\
\hline & & & $15^{\circ}-30^{\circ}$ & 0.7 \\
\hline & & & $5^{\circ}-15^{\circ}$ & 0.2 \\
\hline & & & $<5^{\circ}$ & 0 \\
\hline & \multirow{4}{*}{$\begin{array}{l}\text { Archaeological } \\
\text { Site Factor } \\
\text { (S.F.) }\end{array}$} & \multirow{4}{*}{0.3} & Slope Instability - Relevant Studies & 1 \\
\hline & & & Archaeological indications of slope instability & 0.6 \\
\hline & & & Slope stabilization works & 0.3 \\
\hline & & & None & 0 \\
\hline & \multirow{5}{*}{$\begin{array}{l}\text { Erosion Factor } \\
\text { (E) }\end{array}$} & \multirow{5}{*}{0.2} & $0-20 \mathrm{~m}$ & 1 \\
\hline & & & $20-50 \mathrm{~m}$ & 0.8 \\
\hline & & & $50-200 \mathrm{~m}$ & 0.5 \\
\hline & & & $200-1000 \mathrm{~m}$ & 0.2 \\
\hline & & & $>1000 \mathrm{~m}$ & 0 \\
\hline & \multirow{6}{*}{$\begin{array}{l}\text { Lithology } \\
\quad(\mathrm{L})\end{array}$} & \multirow{6}{*}{0.1} & Flysch & 1 \\
\hline & & & Neogene sediments & 0.9 \\
\hline & & & Recent deposits & 0.75 \\
\hline & & & Metamorphic rocks & 0.35 \\
\hline & & & Carbonate rocks & 0.2 \\
\hline & & & $\begin{array}{l}\text { Igneous volcanic rocks, Schists -cherts } \\
\text { formations }\end{array}$ & 0.1 \\
\hline & \multirow{3}{*}{$\begin{array}{l}\text { Distance to } \\
\text { Tectonic } \\
\text { Lineaments } \\
\text { (D.T.L.) }\end{array}$} & \multirow{3}{*}{0.1} & $<150 \mathrm{~m}$ & 1 \\
\hline & & & $150-300 \mathrm{~m}$ & 0.5 \\
\hline & & & $>300 \mathrm{~m}$ & 0 \\
\hline
\end{tabular}

The lithology factor (L) is based on the susceptibility of lithological groups as classified by IGME and applied in the landslide susceptibility map of Greece, (Sabatakakis et al., 2013 and references therein). These groups are merged into six classes ranked and standardized according to the Landslide Relative Frequency.

Finally, the distance to tectonic lineaments factor (D.T.L.) reflects the effects of active tectonics on the stability of slopes that correlate with extensive fractured zones and steep relief morphology. The definition and classification of buffer zones relating to the distance from tectonic lineaments is a common practice in landslide susceptibility assessment studies characterised by a variety of classes and linear ratings. For the aims of this study the classification and scores by Ladas et al. (2007) are considered as most suitable since the classes are distributed in a way that express satisfactorily the mean tectonic shear attenuation with distance.

\subsection{Tsunami factors}

The susceptibility of an archaeological site to the effects of a tsunami is assessed through the factors of i) inundation depth (I.D.), ii) archaeological site factor (S.F.) and iii) geomorphology (G) (Tab. 4). The linear weighted sum of the factors reflects the potential of an archaeological site to suffer damage from an earthquake induced tsunami expressed through the Tsunami Susceptibility indicator (Eq. 3). 


\section{Equation 3 - Tsunami Susceptibility indicator formula}

$$
T s S i=w 1 I . D .+w 2 S . F .+w 3 G
$$

The inundation depth factor (I.D.) represents a combination of international emergency planning practices with studies performed at a local level, based on historical records of tsunamis in Greece. The $10 \mathrm{~m}$ contour is considered as the mean maximum altitude of potential tsunami inundation depth (Samant et al., 2008, Lekkas et al., 2010) with the first $5 \mathrm{~m}$ contours as the most susceptible zone for tsunami inundation, (Papathoma and Dominey-Howes, 2003), (Tab. 4). The classification includes six classes from 0-2 $\mathrm{m}$ to $>10 \mathrm{~m}$ with scores and standardization assessed with the assistance of the M-MACBETH software.

Table 4 - The spatial susceptibility factors for the Tsunami Susceptibility indicator (TsSi) with weights, classes and scores.

\begin{tabular}{|c|c|c|c|c|}
\hline TsSi & Factor & Weight & Classes & Score \\
\hline \multirow{14}{*}{ שี } & \multirow{6}{*}{$\begin{array}{l}\text { Inundation depth } \\
\text { (I.D.) }\end{array}$} & \multirow{6}{*}{0.7} & $0-2 \mathrm{~m}$ & 1 \\
\hline & & & $2-3 \mathrm{~m}$ & 0.8 \\
\hline & & & $3-4 \mathrm{~m}$ & 0.6 \\
\hline & & & $4-5 \mathrm{~m}$ & 0.4 \\
\hline & & & $5-10 \mathrm{~m}$ & 0.3 \\
\hline & & & $>10 \mathrm{~m}$ & 0 \\
\hline & \multirow{4}{*}{$\begin{array}{l}\text { Archaeological } \\
\text { site factor } \\
\text { (S.F.) }\end{array}$} & \multirow{4}{*}{0.2} & Historical Records and studies & 1 \\
\hline & & & Historical Records & 0.6 \\
\hline & & & High Energy event studies & 0.3 \\
\hline & & & None & 0 \\
\hline & \multirow{4}{*}{$\begin{array}{l}\text { Geomorphology } \\
\text { (G) }\end{array}$} & \multirow{4}{*}{0.1} & Estuarine & 1 \\
\hline & & & Shallow coast & 0.6 \\
\hline & & & Elevated coast & 0.5 \\
\hline & & & Not coastal site & 0 \\
\hline
\end{tabular}

Regarding the archaeological site factor (S.F.) for this effect, the catalogues of historical seismicity and tsunamis provide information on whether an archaeological site has suffered damage in the past during a tsunami. However, the Greek catalogues of historical tsunami events include gross errors and inaccuracies that may lead to incorrect assumptions on the return periods and magnitudes of tsunami events (Dominey-Howes, 2002; Papadopoulos and Fokaefs, 2005). Studies that combine systematic investigations of the available documentary and geological records, combined with bathymetric data and modelling of tsunami propagation, run-up and inundation represent the most reliable sources for historical tsunami events (Dominey-Howes, 2002). Consequently, three classes are attributed to this factor, i) historical records and relevant studies that support the validity of the historical record, ii) historical record without relevant studies and iii) high energy event studies that although they correlate with historical seismic events, they do not correlate with historical tsunami records. The classes are scored according to their degree of relevance to the tsunami effect.

Recent post-tsunami studies indicate a direct relationship between run-up, inundation, degree of sediment deposition and erosion with coastal geomorphology (Chandrasekar et al., 2012; Tanaka et al., 2012). Tsunami impacts are controlled mainly by the coastal configuration and local geographic setting with maximum run up and inundation extent along estuarine coasts and minimum run up and inundation along elevated coasts suggesting that a steep topographic coastal setting is less affected in relation to estuarine coastal topography that is highly affected. In this study the quantitative statistical data provided by the study of Chandrasekar et al. (2012) for the relationship between inundation and coastal geomorphology were standardized for each class of the geomorphology factor $(G)$. 


\subsection{Spatial Susceptibility index (SSi)}

The susceptibility of the archaeological sites to the Earthquake Environmental Effects (EEEs) of liquefaction, landslides and tsunamis, is expressed through the Spatial Susceptibility index (SSi). The index is composed by the equally weighted sum of the susceptibility indicators expressed through Equation 4, standardized in a scale from 0 (not susceptible) to 1 (very high susceptibility) and expressed qualitatively through five susceptibility classes (Tab. 5).

\section{Equation 4 - Spatial Susceptibility index formula}

$$
S S i=\frac{L q S i+L s S i+T S S i}{3}
$$

The index expresses the susceptibility of each archaeological site to the EEEs of ground liquefaction, landslides and tsunamis and allows their relative prioritization at a national and regional level.

Table 5 - Qualitative classification of the Spatial Susceptibility index.

\begin{tabular}{|c|c|c|c|c|c|}
\hline \multicolumn{7}{|c|}{ Spatial Susceptibility index } \\
\hline Description & Not Susceptible & Low & Moderate & High & Very High \\
\hline Value & $\mathbf{0 - 0 . 2}$ & $\mathbf{0 . 2 - 0 . 4}$ & $\mathbf{0 . 4 - 0 . 6}$ & $\mathbf{0 . 6 - 0 . 8}$ & $\mathbf{0 . 8 - 1}$ \\
\hline
\end{tabular}

\section{Results}

The application of the method to the archaeological sites under study (Tab. 6, Fig. 1) allowed the identification of the most susceptible sites to the secondary EEEs, the nature of the effects and their relative contribution to the site's susceptibility. The results highlight the archaeological sites of Lechaion harbour (0.76) and Kenchreai harbour (0.684) in Corinth, the Neratzia Fortress in Kos (0.617) and Heraion in Samos (0.610) as the most susceptible sites to EEEs. Their high susceptibility is mainly attributed to their coastal setting and depositional environments that in combination with poor geotechnical properties mainly favour the induction of ground liquefaction and on shore tsunami impacts.

Moderate index scores are attributed to sites with very high susceptibility to at least one effect or a combination of susceptibilities to more than one effect. For example, the index score for the archaeological site of Logothetis Castle (0.412) is attributed to its very high susceptibility to landslides and to its low susceptibility to tsunami, while the Ancient Agora in Kos index (0.489) is attributed to high susceptibility to liquefaction and tsunami and low susceptibility to landslides. Low index scores relate to susceptibility to only one effect- that of landslides, attributed mainly to the location of the sites at higher altitudes, e.g. Ancient Thera (0.253) to the geological properties of the substratum, e.g. Ancient Agora in Corinth (0.251) and archaeological indications of ground instabilities e.g. Asklepieion (0.256). Finally, the archaeological site of Odeion in Ancient Corinth is the site with the lowest index value (0.071) and is considered as not susceptible to EEEs.

Although the indicators highlighted archaeological sites with very high susceptibility, the Spatial Susceptibility index (SSi) indicates that no site is characterised by very high susceptibility. This is attributed to the fact that in order for a site to have very high susceptibility, it must present high or very high susceptibility to all three effects of ground liquefaction, landslides and tsunami, a condition that can be considered as exceptional and was not encountered during the field surveys on the sites.

The spatial distribution of susceptibility is a useful tool for various end-users since it allows the relative susceptibility assessment at a regional level (Fig. 1). The region of Corinth has archaeological sites ranging from not susceptible (Odeion) to highly susceptible (Lechaion, harbour, Kenchreai harbour). Samos and Kos archaeological sites range from low to high susceptibility, while both of the Santorini sites are assessed with low susceptibility. The assessment at a regional level allows the direct identification and prioritization of the regions and their sites that need to be addressed with further studies and measures according to the EEEs proposed by the Spatial Susceptibility index. 
Table 6 - Regional distribution of the Spatial Susceptibility index for the archaeological sites under study. Sites under very high susceptibility to EEEs in bold.

\begin{tabular}{|c|c|c|c|c|}
\hline $\begin{array}{c}\text { Archaeological S } \\
\text { ites }\end{array}$ & $\begin{array}{l}\text { Liquefaction indi } \\
\text { cator }(L q S i)\end{array}$ & $\begin{array}{l}\text { Landslide indicat } \\
\text { or }(L s S i)\end{array}$ & $\begin{array}{l}\text { Tsunami indicat } \\
\text { or }(T S S i)\end{array}$ & $\mathbf{S S i}$ \\
\hline \multicolumn{5}{|l|}{ Ancient Corinth } \\
\hline Agora & 0.08 & 0.675 & 0 & 0.251 \\
\hline Theatre & 0.66 & 0.55 & 0 & 0.403 \\
\hline Odeion & 0.08 & 0.135 & 0 & 0.071 \\
\hline Lechaion & 1 & 0.425 & 0.86 & 0.76 \\
\hline Kenchreai & 0.96 & 0.335 & 0.76 & 0.684 \\
\hline \multicolumn{5}{|l|}{ Kos } \\
\hline Neratzia Fortress & 0.74 & 0.235 & 0.88 & 0.617 \\
\hline Ancient Agora & 0.695 & 0.175 & 0.6 & 0.489 \\
\hline West Arch. Site & 0.68 & 0.175 & 0.4 & 0.417 \\
\hline Altar of Dionysus & 0.62 & 0.115 & 0.4 & 0.377 \\
\hline Asklepieion & 0.03 & 0.74 & 0 & 0.256 \\
\hline \multicolumn{5}{|l|}{ Samos } \\
\hline Heraion & 0.80 & 0.275 & 0.76 & 0.610 \\
\hline Roman Baths & 0.9 & 0.175 & 0.62 & 0.564 \\
\hline Eupalinos Tunnel & 0 & 0.73 & 0 & 0.243 \\
\hline Logothetis Castle & 0.09 & 0.89 & 0.26 & 0.412 \\
\hline \multicolumn{5}{|l|}{ Santorini sites } \\
\hline Akrotiri & 0.26 & 0.505 & 0 & 0.248 \\
\hline Ancient Thera & 0 & 0.76 & 0 & 0.253 \\
\hline
\end{tabular}

\section{Conclusions}

The results indicate that the majority of the archaeological sites under study are susceptible to at least one Earthquake Environmental Effect. Overall, four archaeological sites (Lechaion and Kenchreai habours in Corinth, Neratzia Fortress in Kos and Heraion in Samos) present high susceptibility to EEEs. Moderate susceptibility is attributed to five sites while six sites are characterized by low susceptibility and only one site (Odeion) is considered as not susceptible.

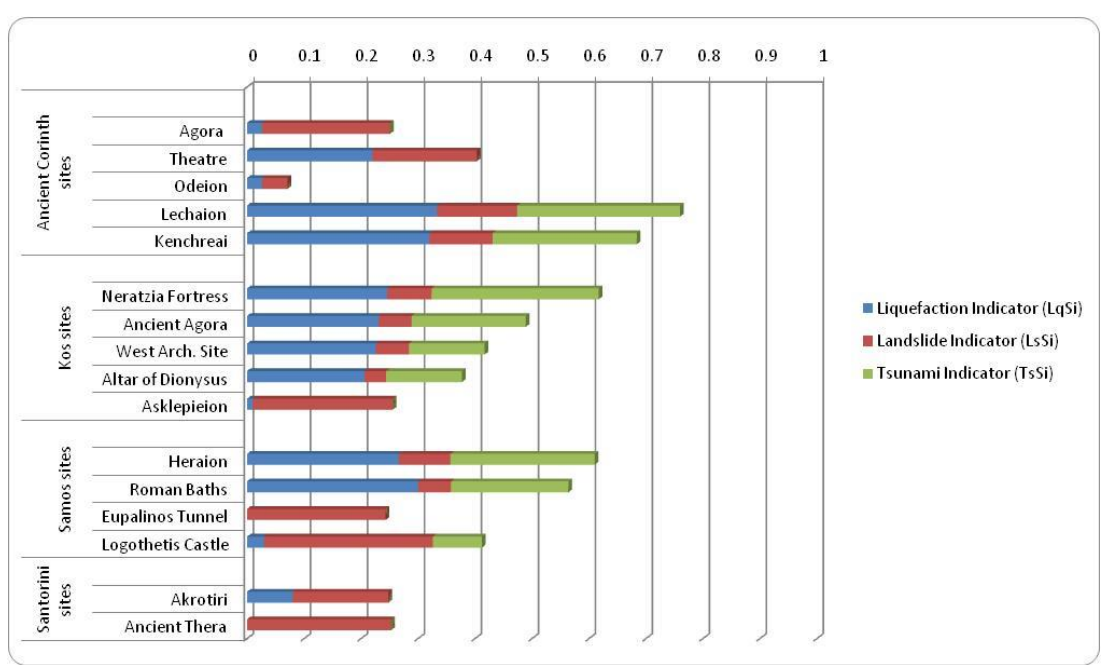

Figure 1 - The Spatial Susceptibility index with indicators contribution for the archaeological sites under study. 
Therefore, the results of this study suggest that the vulnerability assessment of archaeological sites to earthquake hazard should not only be limited to the physical vulnerability of the monuments to ground shaking commonly assessed through vulnerability curves but also include potential damages and degradation effects as a result of ground deformation processes induced by EEEs. The proposed method allows the identification of the EEEs that archaeological sites are susceptible to and prioritization of the sites at a national and regional level through the Spatial Susceptibility index ( $\mathrm{SSi}$ ) for further site specific vulnerability assessment studies and appropriate measures for effective cultural heritage protection against the earthquake hazard.

\section{References}

Alves, F.L., Coelho, C., Coelho, C.D. and Pinto, P., 2011. Modelling Coastal Vulnerabilities - Tool for Decision Support System at Inter-municipality Level, Journal of Coastal Research, SI 64 (Proceedings of the 11th International Coastal Symposium), 966-970. Szczecin, Poland, ISSN 0749-0208.

Bana e Costa, C.A., De Corte, J. M. and Vansnick, J.C., 2005. On the mathematical foundations of MACBETH. In: Figueira, J., Greco, S. and Ehrgott, M., eds., Multiple Criteria Decision Analysis: State of the Art Surveys, Springer.

Chandrasekar, N., Saravanan, S., Pajamanickam, M., Hentry, C. and Rajamanickam, G.V., 2012. Correlation between coastal geomorphology and tsunami inundation along the coast of Kanyakumari, India, J. Ocean Univ. China, 11(1), 1-6.

Dominey-Howes, D., 2002. Documentary and Geological Records of Tsunamis in the Aegean Sea Region of Greece and their Potential Value to Risk Assessment and Disaster Management, Natural Hazards, 25, 195-224.

Jigyasu, R., 2005. Towards developing methodology for integrated risk management of cultural heritage sites and their settings, Proceedings of the ICOMOS $15^{\text {th }}$ General Assembly and scientific symposium, Xi'an, China, 17-21 October 2005, Section II, paper no. 16.

Kouli, M., Loupasakis, C., Soupios, P., Rozos, D. and Vallianatos, F., 2014. Landslide susceptibility mapping by comparing the WLC and WofE multi-criteria methods in the West Crete Island, Greece, Environ. Earth Sci., 72, 5197-5219.

Ladas, I., Fountoulis, I. and Mariolakos, I., 2007. Large scale landslide susceptibility mapping using GIS-based weighted linear combination and multicriteria decision analysis - a case study in northern Messinia (SW Peloponnesus, Greece), Proceedings of the $8^{\text {th }}$ Conference of the Hellenic Geographical Society, pub. no. 119.

Lekkas, E., Minos-Minopoulos, D. and Stefanidou, E., 2010. Emergency planning for the municipality of Kos, Kos Island, Greece. In: Williams et al., eds., 2010, Geologically Active, Taylor \& Francis Group, London, ISBN 978-0-415-60034-7.

Michetti, A.M., Esposito, E., Guerrieri, L., Porfido, S., Serva, L., Tatevossian, R., Vittori, E., Audemard, F., Azuma, T., Clague, J., Comerci, V., Gürpinar, A., McCaplin, J., Mohammadioun, B., Mörner, N.A., Ota, Y. and Roghozin, E., 2007. Intensity scale ESI 2007. In: Guerrieri, L. and Vittori, E., eds., Mem. Descr. Carta Geol. D'It., LXXIV, 73 pp.

Michetti, A.M., Esposito, E., Guerrieri, L., Porfido, S., Serva, L., Tatevossian, R., Vittori, E., Audemard, F., Azuma, T., Clague, J., Comerci, V., Gürpinar, A., McCaplin, J., Mohammadioun, B., Mörner, N.A., Ota, Y. and Roghozin, E., 2015. Environmental Seismic Intensity scale - ESI 2007 (English). In: Guerrieri, L., ed., Earthquake Environmental Effects for seismic hazard assessment: the ESI intensity scale and the EEE catalogue, Mem. Descr. Carta Geol. D'It., XCVII, 11-20.

Minos-Minopoulos, D., 2015. Vulnerability and Risk of archaeological sites to geological geomorphological processes, Unpublished $\mathrm{PhD}$ thesis, Harokopio University, $382 \mathrm{pp}$.

Obermeier, S.F., Jacobson, R.B., Smoot, J.P., Weems, R.E., Gohn, G.S., Monroe, J.E. and Powars, D.S., 1990. Earthquake-induced liquefaction features in the Coastal setting of South Carolina and in the Fluvial setting of the New Madrid Seismic Zone, USGS Professional paper, 1504. 
Obermeier, S.F., 2009. Using liquefaction-induced and other soft-sediment features for paleoseismic analysis. In: McCaplin, J., ed., Paleoseismology, International Geophysics, 95, doi: 10.1016/S0074-6142(09)95007-0.

Papadopoulos, G. and Fokaefs, A., 2005. Strong tsunamis in the Mediterranean Sea: a re-evaluation, ISET Journal of Earthquake Technology, 463, 42, 4, 159-170.

Papathoma, M. and Dominey-Howes, D., 2003. Tsunami vulnerability assessment and its implications for coastal hazard analysis and disaster management planning, Gulf of Corinth, Greece, Natural Hazards and Earth System Sciences, 3, 733-747.

Rodríguez-Pascua, M.A., Pérez-López, R., Giner-Robles, J.L., Silva, P.G., Garduňo-Monroy, V.H. and Reicherter, K., 2011. A comprehensive classification of Earthquake Archaeological Effects (EAE) in archaeoseismology: Application to ancient remains of Roman and Mesoamerical cultures, Quaternary International, 242, 20-30.

Saaty, R.W., 1987. The Analytic Hierarchy Process - What it is and how it is used, Math Modelling, 9, 3-5, 161-176.

Sabatakakis, N., Koukis, G., Vassiliades, E. and Lainas, S., 2013. Landslide susceptibility zonation in Greece, Nat. Hazards, 65, 523-543.

Samant, L.D., Tobin, L.T. and Tucker, B., 2008. Preparing your community for tsunamis: A guidebook for local advocates, Geohazards International, Working Draft, Version 2.1.

Serva, L., Blumetti, A.M., Esposito, E., Guerrieri, L., Michetti, A.M., Okumura, K., Porfido, S., Reicherter, K., Silva, P.G. and Vittori, E., 2015. Earthquake Environmental Effects and seismic hazard assessment: The lessons of some recent large earthquakes, Mem. Descr. Carta Geol. D'It., XCVII, 5-8.

Tanaka, H., Tinh, N.X., Umeda, M., Hirao, R., Pradjoko, E., Mano, A. and Udo, K., 2012. Coastal and estuarine morphology changes induced by the 2011 Great East Japan earthquake tsunami, Coastal Engineering Journal, 54, 1, 1250010.

UNESCO, 2010. Managing Disaster Risks for World Heritage, World Heritage Resource Manual, UNESCO, Available online at: http://whc.unesco.org/en/activities/630/.

Youd, T.L. and Hoose, S.N., 1977. Liquefaction susceptibility and geologic setting, World Conference on Earthquake Engineering, 6th, New Delhi 1977, Proceedings, 3, 2189-2194.

Youd, T.L. and Perkins, D.M., 1978. Mapping liquefaction-induced ground failure potential. Proceedings of the American Society of Civil Engineers, Journal of the Geotechnical Engineering Division, 104, GT4, 433-446.

Youd, T.L., 1998. Screening Guide for Rapid Assessment of Liquefaction Hazard at Highway Bridge Sites. Technical Report MCEER-98-0005, Multidisciplinary Centre for Earthquake Engineering Research, State University of New York, Buffalo, 76 pp. 